\title{
Evaluation of the precipitation for South-western Germany from high resolution simulations with regional climate models
}

\author{
HENDRIK FELdMANN ${ }^{1 *}$, BARbARA FrÜH ${ }^{1}$, GERD SCHÄDLER ${ }^{1}$, HANS-JÜRGEN PANITZ ${ }^{1}$, \\ Klaus KeUleR ${ }^{2}$, DANIElA JACOB ${ }^{3}$ and PHILIP LORENZ ${ }^{3}$ \\ ${ }^{1}$ Institute for Meteorology and Climate Research, Karlsruhe Research Centre and University of Karlsruhe, \\ Germany \\ ${ }^{2}$ Chair of Environmental Meteorology, Brandenburg University of Technology Cottbus \\ ${ }^{3}$ Max Planck Institute for Meteorology, Hamburg, Germany
}

(Manuscript received November 22, 2007; in revised form April 27, 2008; accepted April 27, 2008)

\begin{abstract}
Precipitation data from long-term high-resolution simulations with two regional climate models (CLM and REMO) are evaluated using a climatology based on observations for south-western Germany. Both models are driven by a present day climate forcing scenario from the global climate model ECHAM5. The climatological evaluation shows a strong seasonal dependence of the model deficiencies. In spring and summer there are relatively small differences between simulation results and observations. But during winter both the regional models and ECHAM5 strongly overestimate the precipitation. The frequency distributions of the model results agree well with observed data. An overestimation of the precipitation at the upwind sides of mountainous areas occurs in the regional simulations. We found that the coupling of the regional models to the driving model is stronger in winter than in summer. Therefore, in winter the large scale model have a larger impact on the performance of the regional simulations. During summer the benefit of regional climate simulations is higher.
\end{abstract}

\section{Zusammenfassung}

Die vorliegende Arbeit beschreibt die Ergebnisse der Evaluierung des Niederschlags von zwei hoch aufgelösten Simulationen mit den regionalen Klimamodellen CLM und REMO für die Region SüdwestDeutschland. Dazu wurde eine auf Beobachtungen basierende Klimatologie benutzt. Die Randwerte beider regionalen Modelle stammen von dem globalen Klimamodell ECHAM5, welches Antriebsdaten für das zwanzigste Jahrhundert verwendet. Die klimatologische Evaluierung zeigt eine starke jahreszeitliche Abhängigkeit der Übereinstimmung. Beide regionalen Modelle zeigen geringe Abweichungen zu den Beobachtungen im Frühjahr und Sommer. Im Winter allerdings überschätzen sowohl CLM und REMO als auch ECHAM5 die Niederschläge deutlich. Die Häufigkeitsverteilung des Niederschlags stimmt bei den Modellergebnissen gut mit den Beobachtungen überein. In den regionalen Simulationen tritt eine Überschätzung der Niederschläge an den windwärts gelegenen Seiten von gebirgigen Regionen auf. Die vorliegende Studie zeigt, dass die Kopplung zwischen regionalem und globalem Modell im Winter stärker ist als im Sommer. Daher hat das Verhalten des globalen Modells im Winter einen größeren Einfluss. Im Sommer ist der Gewinn durch die regionalen Klimasimulationen höher.

\section{Introduction}

Although climate change occurs on a global scale its impact varies substantially on local and regional scales (Good and Lowe, 2006). Typically, global climate models with a coarse resolution are used to study the effects of rising greenhouse gas concentrations. These models are not suitable to estimate the impact of global change on the regional scale. Therefore, the information obtained by global scale models has to be transferred to smaller scales. A frequently used method to obtain a higher degree of detail in climate projections is achieved by dynamical downscaling using regional (i.e. limited area) climate models (RCM). These RCMs are driven

\footnotetext{
${ }^{*}$ Corresponding author: Hendrik Feldmann, Tropospheric Research Division, Institute of Meteorology and Climate Research, University/Forschungszentrum Karlsruhe, Postfach 3640, 76021 Karlsruhe, Germany, e-mail: Hendrik.feldmann@imk.fzk.de
}

by global circulation models (GCM) or by analysed meteorological fields at the boundary of the model domain. The use of analysed meteorology excludes errors in the RCM simulations introduced due to biased boundary conditions from the driving GCM. But for a future scenario there is no possibility to apply analysed "perfect" boundary conditions and one has to rely on GCMderived boundary conditions.

For the evaluation of such climate mode applications actual observations and present day climate (PDC) simulations with corresponding forcing are commonly used. The comparison cannot be performed in an event-based mode because the climate model does not reproduce weather of a certain date, but only describes the statistics of climate parameters correctly. Therefore the evaluation requires climatological time scales.

During the last decade the number of experiments studying climate change on the regional scale has grown 


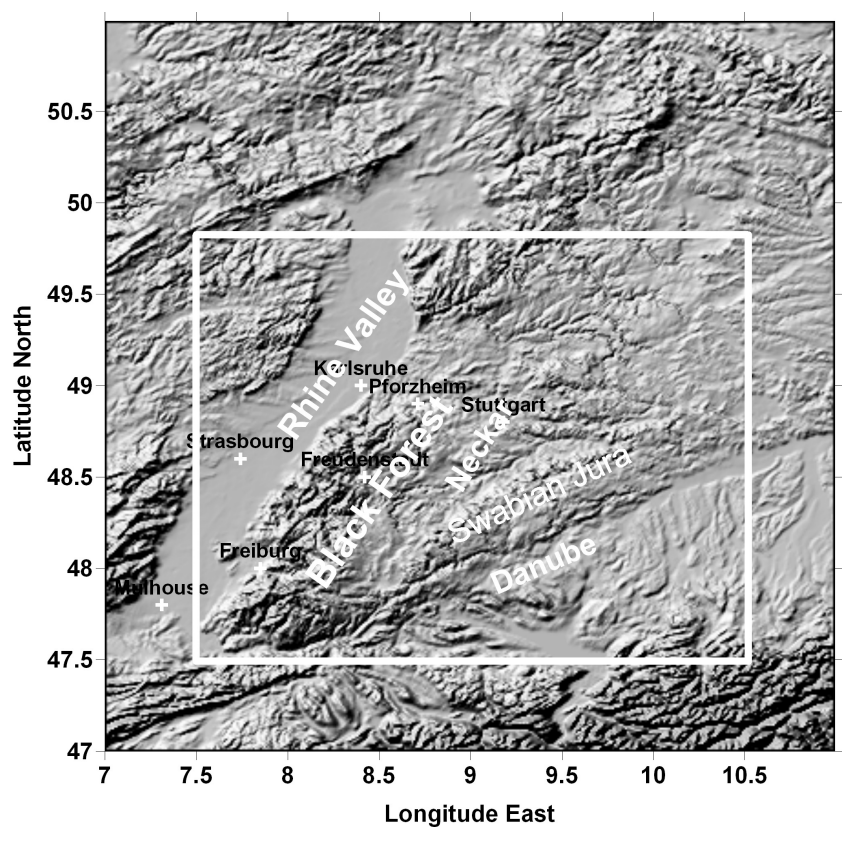

Figure 1: Orography of south-western Germany. The box indicates the region used for the analysis.

largely (IPCC, 2007, chapter 11, CHRISTENSEN et al., 2007). The typical grid size of such simulations is in the order of $50 \mathrm{~km}$. In most cases higher resolved applications cover only periods up to a few years (for instance KLEINN et al., 2005). However, for evaluation of the climatology a time span of several decades should be used (IPCC, 2001).

A study by JАСОB et al. (2007) also includes a longterm evaluation of the precipitation for a large number of regional climate models driven by PDC forcing simulations. They found a common tendency of the models to overestimate winter precipitation in Central Europe. For summer there was no clear tendency for the model bias. The grid resolution of the model simulations in that study was about $50 \mathrm{~km}$. This still seems to be too coarse to describe realistically the horizontal scales of some typical topographical structures in Europe and their effect on climate variables like precipitation.

Recently, two RCM simulations for Europe have become available with grid resolutions below $20 \mathrm{~km}$. This is at the high end of current regional longterm climate simulations (IPCC, 2007, Chapter 11). These simulations were the motivation for this paper, which is focussed on the comparison and evaluation of these simulations namely on the so called "consortium runs" (named CLM-CR hereafter) with the CLM model (WILL et al., submitted) and the so called "REMOUBA" simulations, generated on behalf of the Federal Environment Agency of Germany by the Max-Planck Institute for Meteorology, Hamburg, using the REMO regional climate model (JACOB, 2001). Both data sets are widely used within the regional climate research for Central Europe. Therefore a detailed evaluation is important.
The purpose of this paper is to quantify how well precipitation characteristics are simulated by two different RCMs with different simulation configurations. The analysis is deliberatly restricted to a small region with a substantial topographical variation on scales very close to the resolutions of the models. The reproduction of the spatial precipitation distribution in such a region poses a great challenge for the state of the art RCMs. The comparison of both simulations provides an idea of how much regional climate simulations differ and which features of agreement or disagreements with observations are common despite the differences in model configuration. However, due to several disagreements in the configuration of the simulations (domain, resolution, nesting levels etc.) the analysis does not allow addressing the differences to specific configuration characteristics.

The paper is structured as follows: Section 2 gives an overview over the evaluated RCMs. Adequate observations are crucial for model evaluation. The method to obtain the necessary high-resolution precipitation climatology is described in section 3 . In section 4 we evaluate the precipitation fields of the simulations. In addition the coupling between the RCM and the driving global model and its impacts are studied. Conclusions are given in section 5.

\section{Description of models and experiments}

Within this study we use the results of two RCM simulations, namely the REMO-UBA simulations (grid resolution: $0.088^{\circ} ; \approx 10 \mathrm{~km}$ ) commissioned by the German Federal Environmental Agency (UBA) with the hydrostatic regional model REMO (JACOB, 2001) and the so-called consortium runs (CLM-CR here after, HoLLWEG et al., 2008; resolution: $\left.0.165^{\circ} ; \approx 18 \mathrm{~km}\right)$ performed with the non-hydrostatic model CLM (WILL et al., 2008). A brief overview regarding models and the simulation setup used is given in Table 1. Both models were derived from routine weather prediction models which are adapted for climate applications.

The model experiments presented are PDC simulations with anthropogenic forcing for the $20^{\text {th }}$ century (C20) which cover the period from 1960 to 2000. The 30-year time period between 1971 and 2000 was chosen to get a sufficiently long time span for the comparison of the simulated precipitation climatologies with observed ones.

Both models are driven with data from the global climate model ECHAM5 (ROECKNER et al., 2006a; HAGEMANN et al., 2006; ROECKNER et al., 2006b). The ECHAM5 simulation uses observed anthropogenic forcings for $\mathrm{CO}_{2}, \mathrm{CH}_{4}, \mathrm{~N}_{2} \mathrm{O}, \mathrm{CFCs}, \mathrm{O}_{3}$, and sulphate initialised by a pre-industrial control simulation but neglects natural forcings from volcanoes and changes of the solar activity. The grid resolution is $\mathrm{T} 63\left(1.87^{\circ}\right)$ with 31 layers. The ECHAM5 was run in a coupled mode 
Table 1: Description of the CLM and REMO model setups.

\begin{tabular}{|c|c|c|c|c|}
\hline Model & \multicolumn{2}{|l|}{ CLM } & \multicolumn{2}{|l|}{ REMO } \\
\hline Reference & \multicolumn{2}{|c|}{$\begin{array}{l}\text { Steppeler et al., } 2003 \text { (LM) } \\
\text { Will et al., submitted }\end{array}$} & \multicolumn{2}{|l|}{ Jacob (2001) } \\
\hline Based on & \multicolumn{2}{|c|}{ Local Model LM (non-hydrostatic) } & \multicolumn{2}{|c|}{$\begin{array}{l}\text { Europamodell (hydrostatic) with } \\
\text { parameterizations of ECHAM4 }\end{array}$} \\
\hline Experiment & \multicolumn{2}{|c|}{ Consortium Runs (CLM-CR) } & \multicolumn{2}{|c|}{ UBA Simulations (REMO-UBA) } \\
\hline Resolution & \multicolumn{2}{|c|}{$0.165^{\circ}(\approx 18 \mathrm{~km})$} & \multicolumn{2}{|c|}{$\begin{array}{l}0.088^{\circ}(\approx 10 \mathrm{~km}) \\
0.44^{\circ} \quad(\approx 50 \mathrm{~km}) \text { coarse grid }\end{array}$} \\
\hline Grid points & \multicolumn{2}{|l|}{$257 \times 271$} & \multicolumn{2}{|c|}{$109 \times 121$} \\
\hline Model domain & \multicolumn{2}{|c|}{$\begin{array}{l}32 \\
11 \text { layers below } 2000 \mathrm{~m} \\
\text { rotated pole at } 162^{\circ} \mathrm{W}, 39.25^{\circ} \mathrm{N}\end{array}$} & \multicolumn{2}{|c|}{$\begin{array}{l}27 \\
8 \text { layers below } 2000 \mathrm{~m} \\
\text { rotated pole at: } 162^{\circ} \mathrm{W}, 39.25^{\circ} \mathrm{N}\end{array}$} \\
\hline \multirow{2}{*}{ Model domain } & $\begin{array}{l}\text { lower left: } \\
\text { upper left: } \\
\text { lower right: } \\
\text { upper right: }\end{array}$ & $\begin{array}{r}7.46^{\circ} \mathrm{W}, 24.24^{\circ} \mathrm{N} \\
40.97^{\circ} \mathrm{W}, 62.81^{\circ} \mathrm{N} \\
35.81^{\circ} \mathrm{E}, 26.49^{\circ} \mathrm{N} \\
63.95^{\circ} \mathrm{E}, 67.65^{\circ} \mathrm{N}\end{array}$ & $\begin{array}{l}\text { coarse grid: } \\
\text { lower left: } \\
\text { upper left: } \\
\text { lower right: } \\
\text { upper right: }\end{array}$ & $\begin{array}{r}7.53^{\circ} \mathrm{W}, 19.82^{\circ} \mathrm{N} \\
50.51^{\circ} \mathrm{W}, 64.22^{\circ} \mathrm{N} \\
37.87^{\circ} \mathrm{E}, 21.69^{\circ} \mathrm{N} \\
77.70^{\circ} \mathrm{E}, 68.58^{\circ} \mathrm{N}\end{array}$ \\
\hline & & & $\begin{array}{l}\text { inner grid: } \\
\text { lower left: } \\
\text { upper left: } \\
\text { lower right: } \\
\text { upper right: }\end{array}$ & $\begin{array}{r}4.87^{\circ} \mathrm{E}, 44.93^{\circ} \mathrm{N} \\
1.61^{\circ} \mathrm{E}, 55.29^{\circ} \mathrm{N} \\
18.31^{\circ} \mathrm{E}, 45.76^{\circ} \mathrm{N} \\
18.38^{\circ} \mathrm{E}, 56.32^{\circ} \mathrm{N}\end{array}$ \\
\hline Dataset citation & \multicolumn{2}{|c|}{$\begin{array}{l}\text { CLM-CR: Lautenschlager et al. } \\
\text { (2008) }\end{array}$} & \multicolumn{2}{|c|}{ REMO-UBA: Jacob (2005) } \\
\hline
\end{tabular}

with the Max-Planck-Institute ocean model MPI-OM. The CLM-CR simulations were nested directly into the ECHAM5 fields. For REMO-UBA a two step nesting was applied. A REMO simulation with a resolution of $0.44^{\circ}$ is driven by ECHAM5. This coarser REMO simulation provides the boundary values for the high resolution REMO-UBA simulation.

In addition, the precipitation data from re-analysis driven simulations were analysed to compare them with the PDC simulations. The CLM-ERA40 simulations use the same setup as the consortium runs but are driven by ERA40 re-analysis (UPPALA et al., 2005) and cover the period 1979 to 2000 . The REMO-ERA15 simulations were performed on the same grid as REMO-UBA and are driven by ERA15 re-analysis (GIBSON et al., 1999) for the period 1979 to 1993 and ECMWF operational analysis from 1994 to 2000 . The simulation using analysed fields as input reduces the differences between model results and observations caused by potential deviations in the large scale circulation for climate mode applications. It is known that the precipitation fields derived from short term forecasts of the re-analysis can not be used as quasi-observational data (HAGEMANN et al., 2005; ZoLINA et al., 2004) like it is for other meteorological parameters. For example: The amplitude of the annual cycle of the ERA40 precipitation in southwestern Germany is strongly underestimated. Therefore, the ERA-driven simulations are to study the regional distributions. A more detailed analysis of CLM simulations driven by ERA40 can be found in JAEGER et al. (2008) and BACHNER et al. (2008).

Our study area encompasses the region from $7.5^{\circ} \mathrm{E}$ to $10.5^{\circ} \mathrm{E}$ and $47.5^{\circ} \mathrm{N}$ to $49.8^{\circ} \mathrm{N}$ and covers the federal state of Baden-Württemberg (Figure 1), Germany. The horizontal extensions are about $225 \mathrm{~km}$ x $255 \mathrm{~km}$. The area of interest is characterized by a complex topography and includes orographic features like e.g. the Rhine valley, the Black Forest, the Swabian Jura, and the valleys of the Neckar and the upper Danube (Figure 1). The Black Forest oriented nearly in north-south direction. Its highest elevation is the Feldberg with nearly $1500 \mathrm{~m}$ above MSL. Adjacent are the rivers Rhine to the south and west, the Danube to the south-east and the Neckar to the north-east. The Swabian Jura is a high plateau between Neckar and upper Danube with an altitude up to 1000 m MSL.

\section{Observed climatological precipitation}

The evaluation strategy applied within this paper uses monthly and daily (chapter 4.3) observed precipitation data which are interpolated onto the model grids of CLM-CR and REMO-UBA. So, both simulations are compared with the observations in their specific spatial resolution. We employ the sophisticated, high resolution (1.25 min.; $\approx 2 \mathrm{~km}$ ) climatology for the Alpine region (SCHWARB, 2001; SCHWARB et al., 2001; FREI and SCH ÄR, 1998) which combines climatological and statistical concepts for the analysis of orographic precipitation, particularly considering the wind exposure of the specific station and the altitude dependent precipitation amount. It is therefore especially suited for the complex topography in the area of interest. These data are complemented by the precipitation climatology from the German Weather Service (DWD; MüLLERWESTERMEIER, 1995) for the northernmost part of the 


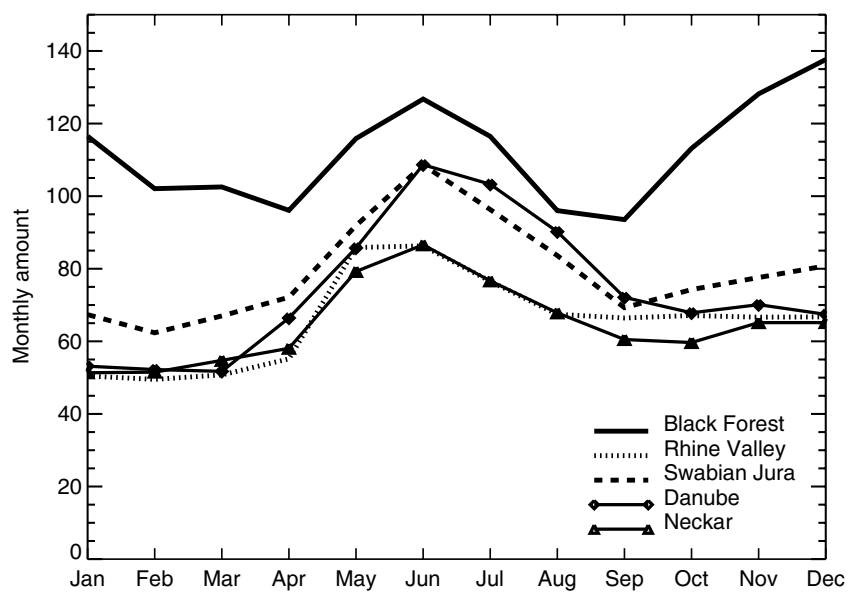

Figure 2: Observed annual cycle of monthly precipitation - for selected regions in south-western Germany (climatology 1971-2000).

area of interest to derive a comprehensive observation data set for the evaluation of the RCMs. The applied approach is described in detail in FRÜH et al. (2006) and FRÜH et al. (2007; for the daily data).

Uncertainties and errors of the observational climatology are addressed in FREI et al. (2003). They discuss known sources of systematic errors: The so called network bias is caused by an undersampling of high elevation areas. A second source of errors is attributed to the systematic undercatch of the rain gauges (SEVRUK, 1985). This bias of the precipitation samples is smaller in summer and at low altitudes (below $600 \mathrm{~m} \mathrm{MSL}$ ). In winter and at high altitudes with a high percentage of snowfall the undercatch can be $\approx 40 \%$ depending on the exposure of the measurement site. The underestimation of the mean precipitation is estimated by FREI et al. (2003) to be $16 \%$ for the Alpine region. For southwestern Germany the bias should be slightly smaller due to the lower average altitudes. Corrections of the annual precipitation calculated within BMU (2000) for Germany result in up to $150 \mathrm{~mm}$ for the Black Forest, $\sim 100 \mathrm{~mm}$ for the Swabian Jura and smaller corrections for the river valleys. The observed climatology was not corrected for these errors due to the lack of information on the exposure of the stations in the network. However, these uncertainties have to be kept in mind for the interpretation of the model deviations.

The observed annual cycle of precipitation in BadenWürttemberg (averaged over the period 1971-2000; not corrected) exhibits in general higher precipitation in summer than in winter with the exception of the Black Forest (Figure 2). The three river valleys receive a similar amount of winter precipitation. The Rhine and Neckar valleys are dryer in summer than the upper Danube region. A summer maximum can also be found for the Swabian Jura. The winter precipitation in the Swabian Jura is higher than in the valleys. The annual precipitation cycle of the Black Forest shows two maxima: one in summer and another even higher one in

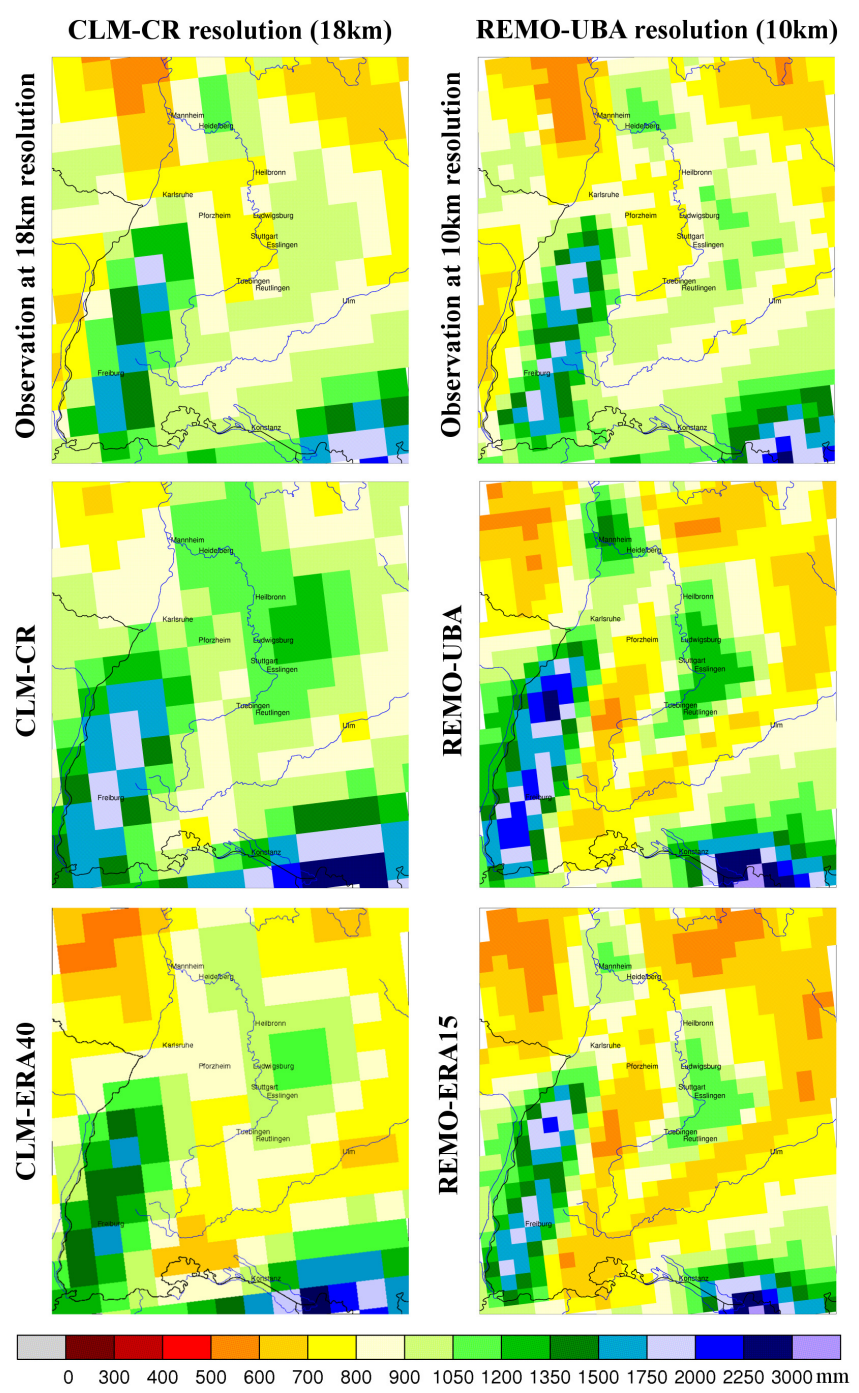

Figure 3: Mean annual precipitation [mm] 1971-2000 (ERA-driven simulations 1979-2000). The observations are displayed in the upper row (left side at CLM-CR resolution; REMO-UBA on the right); middle: CLM-CR (left), REMO-UBA (right); bottom: CLM-ERA40 (left), REMO-ERA15 (right).

winter. This enhanced winter precipitation is caused by orographic lifting mainly on the western side, which is exposed to the dominant flow regime during this season. The annual precipitation amount ranges from about $550 \mathrm{~mm}$ in the Rhine valley to $2000 \mathrm{~mm}$ in the Black Forest (Figure 3). There is also a pronounced lee effect to the east of the Black Forest with reduced precipitation. For the Rhine, Danube and Neckar region the typical annual precipitation amount ranges between 600 and $1000 \mathrm{~mm}$ and for the Swabian Jura between 900 and $1400 \mathrm{~mm}$. The seasonal precipitation sums averaged over the region of interest are $226 \mathrm{~mm}$ (MarchMay, MAM), $285 \mathrm{~mm}$ (June-August, JJA), $228 \mathrm{~mm}$ (September-November, SON) and $214 \mathrm{~mm}$ (DecemberFebruary, DJF). 


\section{Results}

\subsection{Evaluation of the regional precipitation climatology}

Within this section, 30-year mean precipitation sums of different duration (year, month or season) are analysed. Both RCMs are compared to the observations adjusted to their respective spatial resolution to account for the different representation of topography and land cover of both models. A running 3x3-point smoothing was applied to the model data in Figure 3 and 4 to account for the effective model resolution, which is known to be coarser than the grid size.

Comparing the means of the annual total precipitation of CLM-CR and REMO-UBA with observations (Figure 3) the ability of the RCMs to reproduce the orographic pattern of precipitation becomes apparent. A higher amount of precipitation is found in the Alps in the south-east of the domain, the Black Forest and the Swabian Jura compared to the lower amount in the river valleys. The regional patterns generated by the reanalysis driven simulations (lower part of Figure 3) are rather similar to that of the PDC driven experiments for both models. This is an indication that the precipitation distribution is dominated by the regional climate models. The total precipitation is lower for the ERA-driven simulations.

The observed average precipitation for the selected region is $953 \mathrm{~mm}$. Both models produce higher mean annual totals with $1138 \mathrm{~mm}$ (+19\% compared to the observations) for CLM-CR and $1006 \mathrm{~mm}(+6 \%)$ for REMO-UBA. These discrepancies are smaller than the typical deviations for Central Europe using data from a large number of regional climate models with generally coarser grids found by JACOB et al. (2007). The annual total area averaged precipitation of REMO-ERA15 is $887 \mathrm{~mm}(-7 \%)$ and for CLM-ERA40 $948 \mathrm{~mm}(-0.5 \%)$ in Baden-Württemberg. The deviation of the area averaged annual totals derived from the ERA-driven simulations is very low compared to the uncorrected observations. If we additionally take the undercatch of the observations into account, both simulations underestimate the annual precipitation.

REMO-ERA15 is significantly too dry in autumn. The other seasons are only slightly dryer than the observations. CLM-ERA40 overestimates the winter precipitation by about $20 \%$ in winter and simulates too dry conditions in summer $(-14 \%)$ which almost compensate each other and result in an agreement of the annual totals. However, the annual cycle of CLM-ERA40 differs significantly from the observed one.

The precipitation characteristics found for the reanalysis driven RCM simulations are consistent with the precipitation derived from short term forecasts with the ECMWF model driven by ERA (HAGEMANN et al., 2005; ZolinA et al., 2004). HAGEMANN et al. (2005) found for southern Germany a strong dry bias of ERA40
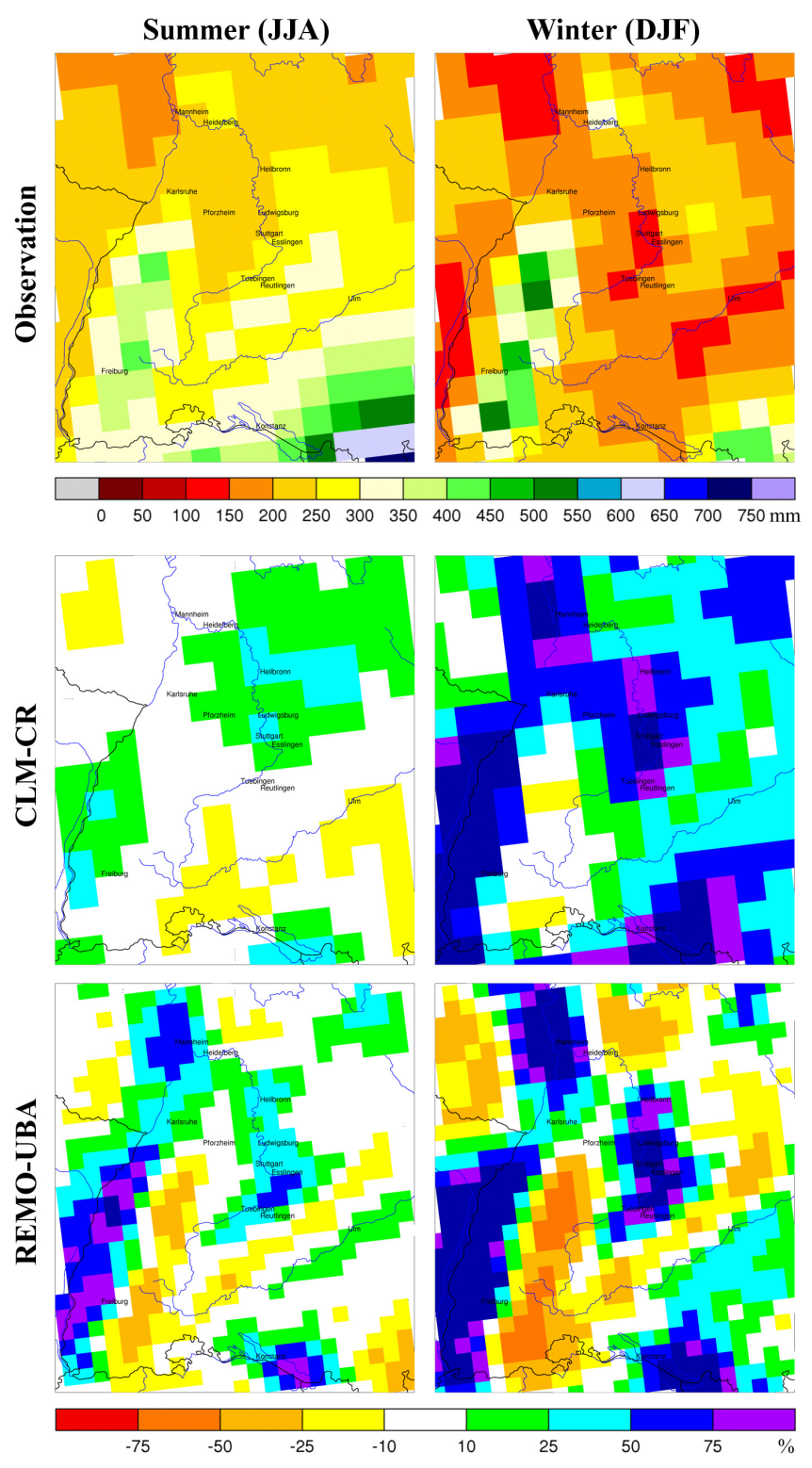

Figure 4: Observed climatological precipitation [mm] (upper row, at CLM-CR resolution); percentage deviation to the gridded observations at the resolution of the models (model - observation)/observation [\%] of CLM-CR (middle row) and REMO-UBA (lower row); left: summer (JJA: June-August), right: Winter (DJF: December-February).

precipitation in summer and of ERA15 in winter compared to the Global Precipitation Climate Project GPCP climatology (HUFFMAN et al., 1997).

The regional variation of the differences between observations and model results is large. The most difficult regions for the models to simulate are the slopes of the Black Forest due to the steep and complex orography. The area affected by the orographically enhanced precipitation amount extends too far into the Rhine valley for both models. BARTHLOTT et al. (2006) pointed out that even an episodic LM simulation with a $7 \mathrm{~km}$ resolution is still too coarse and does not represent the 
local meteorological fields in that region adequately. They found that convective precipitation was initiated too early and widespread. This is consistent with the behaviour of the CLM and REMO simulations analysed here. Our findings for the Black Forest region can be regarded as a typical example for the effect of the topography on the simulated precipitation fields in Central Europe, where we found analogous effects for other lower mountain ranges like e.g. the Vosges, the Harz, etc..

In general CLM-CR agreed well with observations in nearly all parts of the domain during summer (Figure 4, left). The Danube region is slightly too dry. For the Rhine, parts of the Swabian Jura and the hilly areas east of Stuttgart and Heilbronn the precipitation amounts are overestimated. The Spearman rank correlation coefficient $\mathrm{R}_{s p}$ provides information on the spatial agreement between the horizontal distribution of the observed and simulated precipitation. During the summer months $\mathbf{R}_{S p}^{2}$ is in the range 0.6-0.8. In winter there is a strong overestimation of CLM-CR over most of the domain (Figure 4 , right column). The relative deviations of CLM-CR vs. the observations are larger on the upwind side of the elevated regions. This shift leads to a low spatial correlation $\left(\mathrm{R}_{S p}^{2}=0.3\right)$.

The annual totals of the REMO-UBA precipitation show a considerably higher spatial variability compared to the observations and the CLM-CR results (Figure 3 and 4). This large variation cannot be explained by the higher horizontal resolution of REMO alone, but has to be attributed to the formulation of the processes in REMO which affect the redistribution of the atmospheric water. The large differences between the simulated and observed precipitation pattern originates from excess precipitation on the orographic slopes with western to northern exposure and a comparable deficit on the eastern and southern slopes. This characteristic of the REMO-UBA simulation persists throughout the seasons. This misplacement of the precipitation field causes the considerably lower $\mathrm{R}_{S p}^{2}(<0.4)$ values for REMOUBA compared to CLM-CR. The luff/lee contrast for CLM-CR is much less pronounced and no such precipitation deficit can be found east of the Black Forest. This finding also holds for many other topographically structured regions in central Europe which are covered by both models, for instance for the Vosges to the west of the Black Forest, the hilly regions adjacent to the Rhine further north or the Harz.

\subsection{Seasonal variation}

The deviation in the annual total is mainly due to the overprediction for the months November to February (Figure 5). In the winter season (DJF) REMO-UBA has a bias of $+20 \%$ and CLM-CR of $+48 \%$. The climatological annual cycles derived from the RCM are bimodal with a summer and a winter maximum. The observations show only small variations in the months between

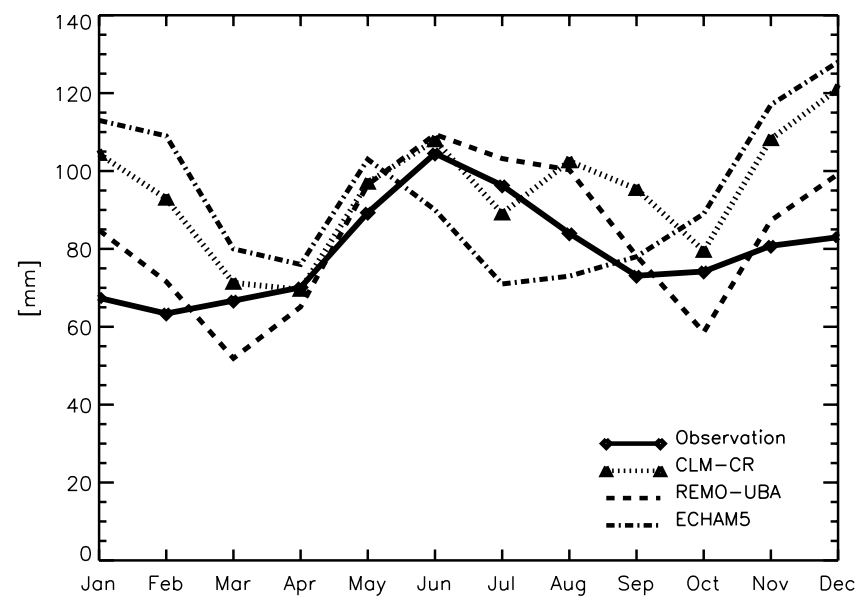

Figure 5: Annual cycle of the monthly climatological precipitation in south-western Germany (mean over the period 1971-2000). The solid curve indicates the observations; CLM-CR (dotted + triangles), REMO-UBA (dashed), and the global model ECHAM5 (dashdotted).

September and April with a minor maximum in December. In contrast, December is the month with the largest amount of precipitation in CLM-CR simulations. For the summer months the bias between the regional models and the observations is below $10 \%$. Both models reproduce the increasing rainfall amount between March and June. The difference between the RCM results and the observation is about 4 to $5 \mathrm{~mm}$ for the maximum in June, which is the wettest summer month in that region. Towards autumn the climatologies indicate dryer monthly averages with a minimum in September (for the observations) and October for the RCMs. The transition months - October and March - are extremely dry in the REMO-UBA results.

We found a very good agreement between the observations and REMO-UBA in spring (MAM; bias -6\%; $-0.14 \mathrm{~mm} /$ day), summer (JJA $+9 \% ; 0.3 \mathrm{~mm} /$ day) and autumn (SON; +2 \%; +0.04 mm/day). In winter there is an overestimation of REMO-UBA of $20 \%$ (DJF; $+0.5 \mathrm{~mm} /$ day). The agreement of the CLM-CR results to the observations is very good in spring $(+5 \%+0.13$ $\mathrm{mm} /$ day $)$ and summer $(+5 \% ;+0.15 \mathrm{~mm} /$ day $)$. The simulation overestimates the precipitation in autumn $(+20 \%$; $0.6 \mathrm{~mm} /$ day $)$ and winter $(+48 \% ;+1.1 \mathrm{~mm} /$ day $)$.

\subsection{Evaluation of the frequency of occurrence}

The ability to reproduce the features of the observed frequency of occurrence is important for climate impact studies e.g. with regard to floods and to assess the reliability of the climate simulations independent of spatial correlation. For this purpose the daily precipitation data of all grid cells in the 30-year time period were binned for the observations and both model simulations. The probability of extreme precipitation intensities is higher for smaller grid cells than averaged over a larger area. In 


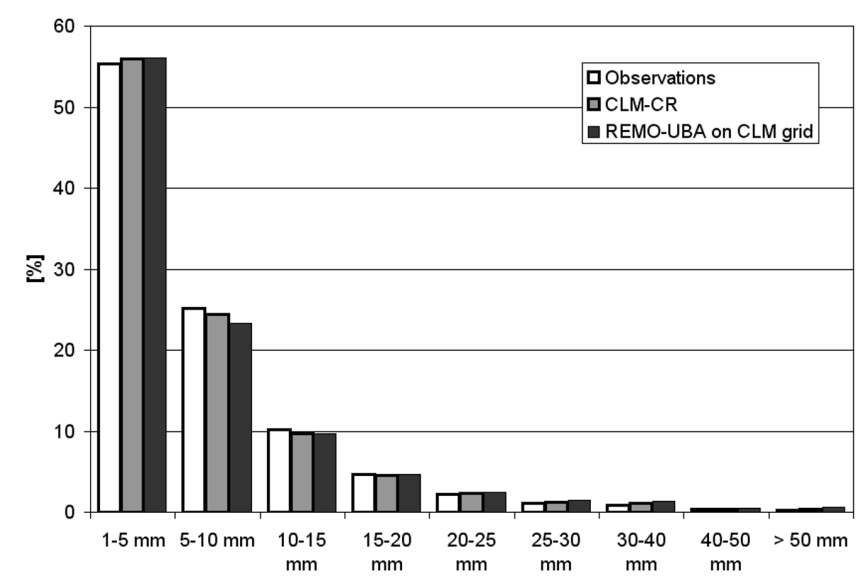

Figure 6: Percentage frequency of occurrence of classified daily precipitation events from observations (white), CLM-CR (grey) and REMO-UBA interpolated to the CLM grid (black) for Baden-Württemberg for the period 1971-2000.

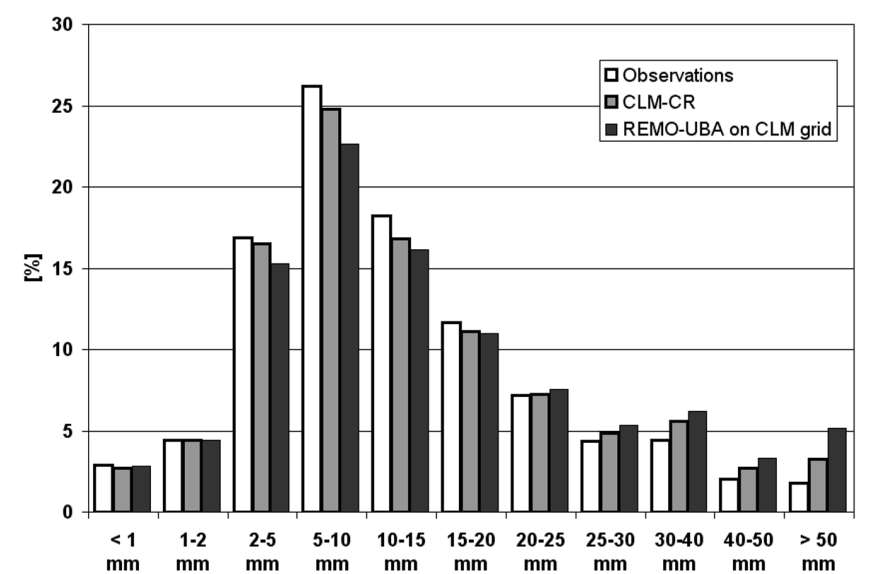

Figure 7: Percentage contribution of each class to the total precipitation from observations (white), CLM-CR (grey) and REMO-UBA interpolated to the CLM grid (black) for Baden-Württemberg over the period 1971-2000.

this section we use observation and REMO-UBA precipitation data interpolated to the grid of CLM-CR to achieve comparable results. As expected the effect of the interpolation of REMO-UBA is small for the lower intensities and leads to a reduction of about $17 \%$ in the number of the extreme events ( $>50 \mathrm{~mm} /$ day) compared to the original resolution.

In the CLM-CR results $54 \%$ of all days are dry days ( $<1 \mathrm{~mm} /$ day), but $61 \%$ of days in the observations. Thus, CLM-CR produces precipitation too often, especially in winter. The fraction of dry days in the REMOUBA simulations is about $61 \%$ and therefore matches the observations.

The frequency distributions of the simulations and observations for days with more than $1 \mathrm{~mm}$ precipitation are rather similar (Figure 6). The fraction of low and moderate precipitation days is marginally lower in the simulations. Both models have a higher percentage of days with more than $25 \mathrm{~mm}$ precipitation, amounting to $3.1 \%$ for CLM-CR and $3.9 \%$ REMO-UBA (at 18 $\mathrm{km}$ resolution; $4.6 \%$ at $10 \mathrm{~km}$ resolution) compared to $2.5 \%$ in the observations (also at $18 \mathrm{~km}$ resolution). The models are able to reproduce the observed increase of these high intensity events from winter to summer (not shown).

For the precipitation amount discrepancies at high but rare intensities play a minor role. Figure 7 shows the contribution of each intensity class to the total amount. For the simulations as well as for the observations the moderate precipitation days $(5-15 \mathrm{~mm} /$ day) give the highest contribution to the total amount. The models slightly underestimate the contribution of intensities below $20 \mathrm{~mm} /$ day and overestimate the higher intensities ( $>25 \mathrm{~mm} /$ day) compared to the observations. This difference is larger for REMO-UBA than for CLM-CR. A more detailed analysis shows that the overestimation of heavy precipitation events is larger in winter than in summer for both models.

\subsection{Regional and large scale processes}

The precipitation field simulated by a RCM is influenced by synoptic scale processes as well as by local scale forcing like e.g. orography and land use. The RCM inherits the large-scale meteorological pattern from the global model (in our case ECHAM5) via the boundary conditions.

Figure 5 suggests a stronger coupling between ECHAM5 and the RCMs in winter than in summer. All three simulations show a similar development between October and May. This might be attributable to the more baroclinic conditions in middle latitudes with stronger cross-boundary flow in winter (WARNER et al., 1997) and therefore a stronger coupling between the driving global model and the RCM, whereas in summer barotropic conditions with weaker coupling prevail. It is also known that ECHAM5 tends to overestimate the winter precipitation in Europe (HAGEMANN et al., 2006). Therefore, the overestimation of the RCMs in winter is at least partly caused by the driving model.

During the summer months - when the small scale processes are more important for the generation of precipitation - the RCM results differ considerably from the too dry ECHAM5 ones and the regional models are able to reproduce the observed area averaged precipitation.

The added value of high-resolution modelling is greater if the (spurious) influence of the GCM does not dominate. To illustrate the degree to which the RCMs depend on ECHAM5 we analysed the correlation for seasonal and annual averages over the time period of 30 years. Figure 8 shows the resulting Spearman rank correlation coefficient. For this investigation an area from $44.5^{\circ} \mathrm{N}-56.5^{\circ} \mathrm{N}$ and $5^{\circ} \mathrm{E}-17^{\circ} \mathrm{E}$ is chosen in order to analyse more ECHAM5 grid cells and include typical precipitation patterns in Germany. 


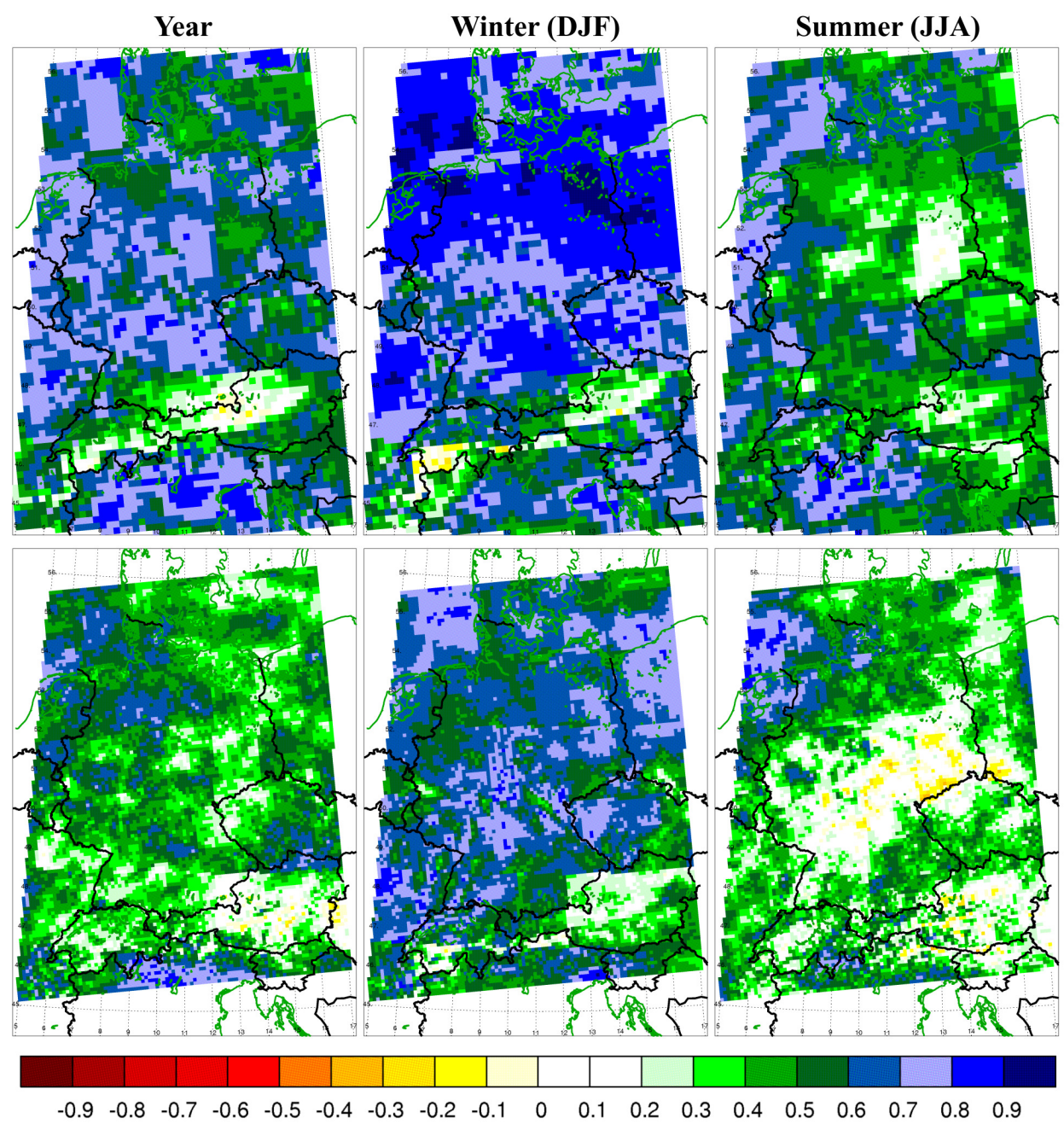

Figure 8: Spearman rank correlation coefficient of the monthly precipitation climatology (1971-2000) between CLM-CR and ECHAM5 (upper row), REMO-UBA and ECHAM5 (lower part) - based on - left: Yearly total precipitation - middle: Winter (DJF) total - right side: Summer (JJA) total.

The correlation of the annual total precipitation time series from ECHAM5 and CLM-CR (Figure 8, upper left) is typically in the range 0.6-0.9 (Spearman rank coefficient) over large parts of the selected area. For many grid cells in the area of mountain ranges the correlation is lower (range: 0.4-0.6). Almost no correlation can be found in the Alps throughout the year (values below 0.3). In this region the representation of the steep topography differs strongly between the coarse resolution GCM and the finer scale RCMs. It cannot be expected that a GCM is able to resolve the processes correctly, which determine the precipitation distribution in high mountain areas. The Spearman rank coefficient for REMO-UBA/ECHAM5 is somewhat lower than CLMCR/ECHAM5 but has a similar spatial structure. In winter (DJF, Figure 8, middle part), compared to the annual totals, the correlations are stronger in large parts of the domain except for the southern and eastern Alps. Even in the area with low mountain ranges - like the Black Forest - the correlation of winter precipitation is much stronger compared to the annual values. In winter pre- cipitation is generated mainly by the synoptic scale ascent of air masses. This process is resolved by large scale models and passed to the RCMs. This leads to a strong dependence of the RCM on the GCM. Therefore, the impact of uncertainties of the large scale driving model on the RCM is larger in winter than in summer.

In summer (JJA, Figure 8, right) there are more regions with low correlation than in winter. Not only the Alps but also areas with low mountain ranges are clearly visible as regions with very low correlation, which indicates that smaller scale topographical features have a major effect on the generation of precipitation in the warm season of the year. But a low correlation can also be found over flat regions like in eastern Germany. Here local convection is likely to cause the differences between the RCMs and ECHAM5. In summer the advantage of regional models with higher spatial resolution and, thus, a more detailed treatment of the physical processes (HAN and ROADS, 2004) becomes effective in producing precipitation fields closer to the observations. 


\section{Conclusions}

In this study we evaluated the precipitation fields derived from long-term simulations of two state of the art high resolution regional climate models (RCM). The focus was on present day climate simulation with the RCMs REMO and CLM which were both driven by the GCM ECHAM5. Therefore, differences within the results of the two simulations arise from the different model formulations and setups and not from the large scale forcing. The intention was to evaluate RCMs in a mode which is applied for projections of future climate.

The study was performed for a region in south-western Germany with complex topography which is a great challenge for the models. The selected region is in the transition area between the northern European and the Mediterranean climate zone, which are expected to have a significantly different sensitivity to climate change (IPCC, 2007).

The analyses covered several important aspects of the precipitation fields: The regional distribution, the annual cycle and the frequency distributions. In addition, the seasonal variation of the dependence of the RCMs from the driving model has been addressed.

The evaluation indicates that with a resolution below $20 \mathrm{~km}$ both models are more capable to resolve the orographical scales which are typical in Central Europe than the $50 \mathrm{~km}$ resolution of the previous generation RCM simulations (e.g. JACOB et al., 2007). But on the other hand they are still too coarse to treat important atmospheric processes like e.g. convection or valley wind circulations explicitly, which affect the regional distribution of precipitation. Therefore, we conclude that the model resolution should be further increased in RCM simulations for regions with complex topography.

The overestimation of precipitation at the upwind side of mountainous areas is characteristic for both RCMs at western to northern mountain slopes. This can be found in many other regions (not only in south-western Germany). The feature appeared as well in the climate mode using ECHAM5 as well as in the simulations driven by re-analysis data. Thus, we conclude that there are some deficits in the model parameterizations of REMO and CLM with regard to orographic precipitation.

The statistics of the simulated precipitation fields showed strong seasonal variations with a good agreement with the observations in summer but an overestimation in winter. Several studies indicate that a positive bias in winter is a quite common feature of regional models for Central Europe (e.g. CHRISTENSEN et al., 2007). The positive bias was found for simulations driven by global climate models (JACOB et al., 2007) as well as for simulations driven by re-analysis fields (KOTLARSKI et al., 2005). The magnitude of winter time differences is put into perspective by the potential underestimation of the observations. The estimate of up to $16 \%$ for the undercatch given by FREI et al. (2003) for the Alps in winter provides an indication for the or- der of magnitude of the undercatch in the measurements. In this context the overestimation of REMO-UBA for December to February becomes negligible. For CLM$\mathrm{CR}$ it is still significant.

Within this study the strong positive precipitation bias in the ECHAM5 simulations combined with the strong coupling the RCMs was shown to be an important aspect for the large errors in wintertime precipitation. This effect is larger than many other potential factors causing discrepancies from the observations. Therefore, the conditions of the driving GCM are more essential (GRAHAM et al., 2007) in winter than in summer for RCM simulations. JACOB et al. (2007) also found this strong dependence on the boundary forcing for winter precipitation. The frequency of occurrence of simulated precipitation days agreed well with the observations for the period 1971-2000. CLM-CR underestimates the number of dry days being one reason for the overestimation of the total precipitation. Both models overestimate the frequency of high intensity precipitation events. The contribution to the total precipitation is slightly shifted from medium intensities towards the extreme events. These effects are more pronounced for REMO-UBA than for CLM-CR.

To summarize we conclude that high-resolution climate models are able to reproduce many aspects of the regional precipitation fields realistically. The increased spatial resolution has a positive effect on the model performance. This gives confidence that both models are able to give reasonable indications of the regional impact of climate change in future scenarios. However, ensemble simulations are needed to asses the uncertainties.

\section{Acknowledgement}

The authors would like to thank the Model and Data Group (M\&D) at the Max Planck Institute for Meteorology, Hamburg, for providing the model data from the CLM, REMO and ECHAM5 simulations. We also want to thank Ch. FreI, M. SChWARB and J. KLEINN for providing us with the PRISM precipitation climatology and the German Weather Service (DWD) for providing us with the precipitation climatology and observations. The work was done within the project "Herausforderung Klimawandel" funded by the "Zukunftsoffensive 4" of the state of Baden-Württemberg, Germany.

\section{List of abbreviations}

C20 climate scenario "forcing of the $20^{\text {th }}$ century"

CLM climate version of the "Local Model" LM of the German Weather Service

DWD German Weather Service

CLM-CR "Consortium Runs", climate simulations with the CLM for Europe

CLM-ERA40 simulation using the same configuration as CLM-CR but driven by ERA40 re-analysis 
ECHAM5 a global climate model

GCM global climate model

GPCP Global Precipitation Climate Project

IPCC Intergovernmental Panel on Climate Change

MPI-OM ocean model of ECHAM5

PDC present day climate forcing

PRISM Parameter-elevation Regression on Independent Slope Model

RCM regional climate model

REMO "Regional Model", regional climate model

REMO-UBA climate simulations with REMO

REMO-ERA15 REMO simulation on the same grid as REMO-UBA, but driven by ERA15

\section{References}

BACHner, S., A. Kapala, C. Simmer, 2008: Evaluation of daily precipitation characteristics in the CLM and their sensitivity to parameterizations. - Meteorol. Z. 17, 407419.

BARthlott, C., U. Corsmeier, C. Meissner, F. Braun, C. Kottmeier, 2006: The influence of mesoscale circulation systems on triggering convective cells over complex terrain. - Atmos. Res. 81, 150-175.

BMU, 2000: Hydrologischer Atlas von Deutschland. - Bundesministerium für Umwelt, Naturschutz und Reaktorsicherheit, Bonn.

Christensen, J.H., B. Hewitson, A. Busuioc, A. Chen, X. Gao, I. Held, R. Jones, R.K. Kolli, W.-T. Kwon, R. Laprise, V. Magaña Rueda, L. MEARns, C.G. MEnÉndez, J. RÄISÄnEn, A. Rinke, A. SARR, P. Whetton, 2007: Regional Climate Projections. - In: Climate Change 2007: The Physical Science Basis. Contribution of Working Group I to the Fourth Assessment Report of the Intergovernmental Panel on Climate Change. Solomon, S., D. Qin, M. Manning, Z. Chen, M. Marquis, K.B. Averyt, M. Tignor, H.L. Miller (Eds.), Cambridge University Press, Cambridge, United Kingdom and New York, NY, USA.

FREI, C., C. SCH ÄR, 1998: A precipitation climatology of the Alps from high-resolution rain-gauge observations. Int. J. Climatol. 18, 873-900.

Frei, C., J.H. Christensen, M. DÉQue, D. Jacob, R.G. JONES, P.L. VIDALE, 2003: Daily Precipitation Statistics in Regional Climate Models: Evaluation and Intercomparison for the European Alps. - J. Geophys. Res. 108, D3, 4124.

FrüH B., J. W. SChIPPER, A. Pfeiffer, V. Wirth, 2006: A pragmatic approach for downscaling precipitation in Alpine Scale Complex Terrain. - Meteorol. Z. 15, 631-646.

FrüH B., J. BendiX, T. NAuss, M. PAulat, A. Pfeiffer, J. W. SChipper, B. Thies, H. WERnli, 2007: Verification of precipitation from regional climate simulations and remote-sensing observations with respect to ground-based observations in the upper Danube catchment. - Meteorol. Z. 16, 275-293.

Gibson, J.K., P. KÅllberg, S. Uppala, A. HernanDEZ, A. Nomura, E. SERrANO, 1999: ERA-15 description, version 2. - ECMWF Re-analysis Report Series 1, ECMWF, Reading, England.

Good, P., J. Lowe, 2006: Emergent behaviour and uncertainty in multimodel climate projections of precipitation trends at small spatial scales. - J. Climate 19, 5554-5569.
Graham, L. Ph., S. Hagemann, S. Jaun, M. Beniston, 2007: On interpreting hydrological change from regional climate models. - Climatic Change 81, 97-122.

Hagemann, S., K. Arpe, L. Bengtsson, 2005: Validation of the hydrological cycle of ERA40. - In: ECMWF ERA-40 Project Report Series, No. 24, European Centre for Medium-Range Weather Forecasts, Reading, UK.

Hagemann, S., K. ARPe, E. RoecKner, 2006: Evaluation of the hydrological cycle in the ECHAM5 model. - J. Climate 19, 3810-3827.

HAN, J., J.O. ROADS, 2004: U.S. climate sensitivity simulated with the NCEP regional spectral model. - Climatic Change 62, 115-154.

H.-D. Hollweg, U. Böhm, I. Fast, B. Hennemuth, K. Keuler, E. Keup-Thiel, M. Lautenschlager, S. LegutKe, K. Radtke, B.T Rockel, M. Schubert, A. Will, M. Woldt,C. Wunram, 2008: Ensemble Simulations over Europe with the Regional Climate Model CLM forced with IPCC AR4 Global Scenarios. - Technical Report No. 3, Model and Data Group at the Max Planck Institute for Meteorology, Hamburg. ISSN printed: 1619-2249, ISSN electronic: 1619-2257

Huffman, G.J., R.F. Adler, A. Arkin, A. Chang, G. Ferraro, A. Gruber, J. Janowiak, R.J. JoyCe, A. McNab, B. Rudolf, U. SchneIder, P. XIE, 1997: The Global Precipitation Climatology Project (GPCP) combined precipitation data set. - Bull. Amer. Meteor. Soc. 78, 5-20.

IPCC, 2001: Climate change - the scientific basis, Intergovernmental Panel on Climate Change. - Cambridge Univ. Press, Cambridge, 944 pp.

- 2007: Climate change 2007: The physical science basis. Contribution of Working Group I to the Fourth Assessment Report of the Intergovernmental Panel on Climate Change, Solomon, S., D. Qin, M. MAnning, Z. Chen, M. MARQuis, K.B. AVERYT, M. TignOR, H.L. Miller (Eds). Cambridge University Press, Cambridge, United Kingdom and New York, NY, USA, 996 pp.

JACOB, D., 2001: A note to the simulation of the annual and inter-annual variability of the water budget over the Baltic Sea drainage basin. - Meteor. Atmos. Phys. 77, 61-73.

- 2005: REMO Climate of the 20th century run, UBA project, 0.088 degree resolution run NO. 006210, $1 \mathrm{H}$ DATA. CERA-DB "REMO_UBA_C20_1_R006210_1H". - http://cerawww.dkrz.de/WDCC/ui/Compact.jsp?acronym=REMO_ UBA_C20_1_R006210_1H

JACOB, D., L. BÄRRING, O.B. ChriSTENSEN, J.H. Christensen, M. Castro, M. Déqué, F. Giorgi, S. Hagemann, M. Hirschi, R. Jones, E. KJEllSTRÖM, G. LENDERINK, B. ROCKEL, E. SANCHEZ, C. SCHÄR, SI. SENEVIRATNE, S. SOMOT, A.VAN Ulden, B. VAN DEN HURK, 2007: An inter-comparison of regional climate models for Europe: design of the experiments and model performance. - Climate Change 81, 3152, DOI:10.1007/s10584-006-9213-4

JAEGER, E.B., I. ANDERS, D. LÜTHI, B. ROCKEL, C. SCHÄR, S.I. SENEVIRATNE, 2008: Analysis of ERA40driven CLM simulations for Europe. - Meteorol. Z. 17, 349-367.

KLEINN J., C. Frei, J. Gurtz, D. LÜthi, P. L. VidAle, C. SCH ̈̈R, 2005: Hydrologic simulations in the Rhine basin driven by a regional climate model. - J. Geophys. Res. 110, D04102, DOI:10.1029/2004JD005143. 
Kotlarski, S., A. Block, U. BÖHM, D. JACOB, K Keuler, R. KNOCHE, D. Rechid, A. WAlter, 2005: Regional climate model simulations as input for hydrological applications: Evaluation of uncertainties. - Adv. Geoscien. 5, 119-125.

Lautenschlager, M., K. Keuler, C. Wunram, E. Keup-Thiel, M. SCHUbert, A. Will, B. ROCKEL, U.BOEHM, 2008: Climate Simulation with CLM, Climate of the $20^{\text {th }}$ Century run no.1, Data Stream 2: European region MPI-M/MaD. World Data Center for Climate, aviable at http://cerawww.dkrz.de/WDCC/ui/Compact.jsp?acronym=CLM_C20 - 1 D2

MÜLLER-WeSTERMEIER, G., 1995: Numerisches Verfahren zu Erstellung klimatologischer Karten. - Berichte des Deutschen Wetterdienstes 193.

Roeckner, E., R. Brokopf, M. Esch, M. Giorgetta, S. Hagemann, L. Kornblueh, E. Manzini, U. Schlese, U. SchulzWEIDA, 2006a: Sensitivity of simulated climate to horizontal and vertical resolution in the ECHAM5 atmosphere model. - J. Climate 19, 3771-3791.

RoECKNer, E., M. LAUTEnsCHLAGER, H. SCHNEIDER, 2006b: IPCC-AR4 MPI-ECHAM5_T63L31 MPIOM_GR1.5L40 20C3M run no.1: atmosphere monthly mean values MPImet/MaD Germany. - World Data Center for Climate, DOI:10.1594/WDCC/EH5-T63L31_OMGR1.5L40_20C_1_MM.

SCHWARB, M., 2001: The alpine precipitation climate evaluation of a high-resolution analysis scheme using comprehensive rain-gauge data. - Diss. ETH No. 13911. Swiss Federal Institute of Technology. Zürich, Switzerland.

Schwarb, M., C. Daly, C. Frei, C. Schär, 2001: Mean annual and seasonal precipitation in the European Alps 1971-1990. - In: Hydrological Atlas of Switzerland. Plates 2.6 and 2.7, Federal Office for Water and Geology, Bern, Switzerland.
SEVRUK, B., 1985: Systematischer Niederschlagsmessfehler in der Schweiz - In: SERVUK, B. (Ed.): Der Niederschlag in der Schweiz. Beiträge zur Geologie der Schweiz. Hydrologie 31, 65-75.

Steppeler, J., G. Doms, U. Schättler, H.W. Bitzer, A. Gassmann, U. Damrath, G. Gregoric, 2003: Meso-gamma scale forecasts using the nonhydrostatic model LM. - Meteor. Atmos. Phys. 82, 75-96.

Uppala, M., P.W. K^̊llberg, A.J. Simmons, U. ANDRAe, V. DA Costa Bechtold, M. Fiorino, J.K. Gibson, J. Haseler, A. Hernandez, G.A. Kelly, X Li, K. Onogi, S. SaArinen, N. Sokka, R.P. Allan, E. Andersson, K. Arpe, M.A. Balmaseda, A.C.M. BeljaARs, L. VAN DE BERG, J. Bildlot,. N. BorMANN, S. CAires, F. Chevallier, A. Dethof, M. Dragosavac, M. Fischer, M. Fuentes, S. HageMANN, E. HólM, B.J. HoSkins, L. IS AKSEN, P.A.E.M. JANSSEn, R. Jenne, A.P. MCNAlly, J.-F. MAhFouf, J.-J. Morcrette, N.A. RAyner, R.W. SAunders, P. Simon, A. Sterl, K.E. Trenberth, A. Untch, D. VASILJEVIC, P. ViTERBO, J. WOOLEN 2005: The ERA40 re-analysis. - Quart. J. Roy. Meteor. Soc. 131, 2961-3012.

WARner, T.T., R.A. PEterson, R.E. Treaton, 1997: A tutorial on lateral boundary conditions as a basis and potetially serious limitation to regional numerical weather prediction. - Bull. Amer. Meteor. Soc. 78, 2599-2617.

Will A., M. BALDAuf, B. Rockel, A. SEIFERT, submitted: Physics and Dynamics of the COSMO-CLM. - Meteorol. Z.

Zolina, O., A. Kapala, C. Simmer, S.K. Gulev, 2004: Analysis of extreme precipitation over Europe from different reanalyses: A comparative assessment. - Global and Planetary Change 44, 129-161. 